\title{
OPERATION OF HYDROLOGIC DATA-COLLECTION
} STATIONS BY THE U. S. GEOLOGICAL SURVEY IN 1995 


\section{OPERATION OF HYDROLOGIC DATA-COLLECTION STATIONS BY THE U. S. GEOLOGICAL SURVEY IN 1995 \\ Compiled by Melvin Lew and Betty Dodds}




\title{
U.S. DEPARTMENT OF THE INTERIOR \\ BRUCE BABBITT, Secretary
}

\author{
U.S. GEOLOGICAL SURVEY \\ Gordon P. Eaton, Director
}

For additional information write to:

Copies of this report can be purchased from:

Chief, Branch of Operational Support U.S. Geological Survey 405 National Center 12201 Sunrise Valley Drive Reston, Virginia 22092

U.S. Geological Survey Earth Science Information Center Open-File Reports Section Box 25286, MS 517 Denver Federal Center Denver, Colorado 80225 
ABSTRACT

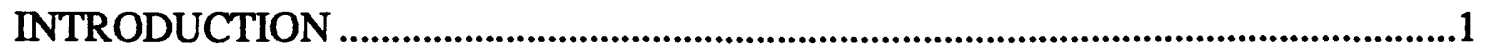

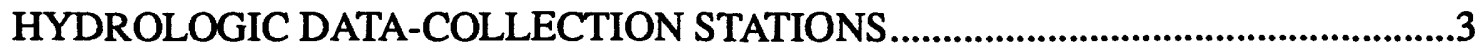

Surface-Water Data ..................................................................................................3

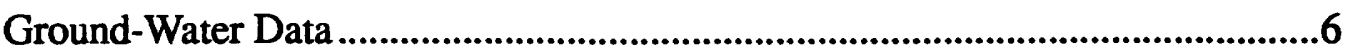

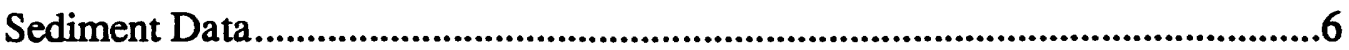

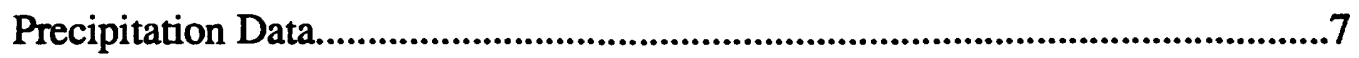

SATELLITE TELEMETRY OF HYDROLOGIC DATA ....................................................

SUMMARY

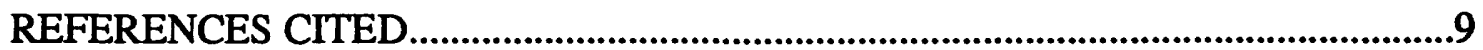

\section{FIGURES}

Figure 1. Map showing number of stations, by State, at which surface-water discharge data were collected in fiscal year 1995 ..........................................10

2. Graph showing number of stations, by year, at which surface-water discharge data were collected from fiscal year 1983 to 1995

3. Map showing number of stations, by State, at which stage-only data were collected on streams in fiscal year 1995.

4. Graph showing number of stations, by year, at which stage-only data were collected on streams from fiscal year 1983 to 1995

5. Map showing number of stations, by State, at which stage data were collected on lakes and reservoirs in fiscal year 1995.

6. Graph showing number of stations, by year, at which surface-water stage data were collected on lakes and reservoirs from fiscal year 1983 to 1995 
7. Map showing number of stations, by State, at which surface-water quality data were collected in fiscal year 1995

8. Graph showing number of stations, by year, at which surface-water quality data were collected from fiscal year 1983 to 1995

9. Map showing number of stations, by State, at which ground-water levels were collected in fiscal year 1995.

10. Graph showing number of stations, by year, at which ground-water levels were collected from fiscal year 1983 to 1995

11. Map showing number of stations, by State, at which ground-water quality data were collected in fiscal year 1995

12. Graph showing number of stations, by year, at which ground-water quality data were collected from fiscal year 1983 to 1995

13. Map showing number of stations, by State, at which sediment data were collected in fiscal year 1995

14. Graph showing the number of stations, by year, at which sediment data were collected from fiscal year 1985 to 1995

15. Map showing number of stations, by State, at which precipitation data were collected in fiscal year 1995

16. Graph showing the number of stations, by year, at which precipitation data were collected from fiscal year 1983 to 1995

17. Map showing number of U.S. Geological Survey stations, by State, at which data-collection platforms for satellite telemetry were operated in fiscal year 1995

18. Diagram showing number of stations at which data-collection platforms for satellite telemetry were operated by the U.S. Geological Survey, and sources of funding support, fiscal year 1995

19. Graph showing the Number of U.S. Geological Survey Stations, by year. at which data-collection platforms for satellite telemetry were operated from fiscal year 1985 to 1995 


\section{TABLES}

TABLE 1. Types and number of hydrologic data-collection stations operated by the U.S. Geological Survey during the 1995 fiscal year, and the sources of funding support.

TABLE 2. Number of continuous surface-water discharge stations, by State and year, from fiscal year 1983 to 1995 ................................................4 


\title{
OPERATION OF HYDROLOGIC DATA-COLLECTION STATIONS BY THE U.S. GEOLOGICAL SURVEY IN 1995
}

\author{
Compiled by Melvin Lew \\ and Betty Dodds
}

\begin{abstract}
The U.S. Geological Survey operates hydrologic data-collection stations nationwide to serve the needs of all levels of government, the private sector, and the general public for water-resources information. During fiscal year 1995, surface-water discharge was determined at 9,639 stations; stage data on streams, reservoirs, and lakes were recorded at 2,037 stations; and various surface-water quality characteristics were determined at 2,979 stations. In addition, ground-water levels were measured at 31,011 sites, and the quality of ground water was determined at 6,280 sites. Data on sediment were collected daily at 148 stations and on a periodic basis at 1,032 stations. Information on precipitation quantity was collected at 1,354 stations and the quality of precipitation was analyzed at 47 stations. Data-collection platforms for satellite telemetry of hydrologic information were used at 3,920 U.S. Geological Survey stations. Funding for the hydrologic stations was derived, either solely or in combination, from three major sources--the U.S. Geological Survey's Federal Program appropriation, the Federal-State Cooperative Program, and reimbursements from other Federal agencies.

The number of hydrologic stations operated by the U.S. Geological Survey has varied from year to year since fiscal year 1983. Comparing fiscal year 1983 with 1995, the number of continuousrecord surface-water discharge stations in 1995 was greater by 33; the total number of surfacewater discharge stations, both continuous and partial record, was lower by 1,437 ; surface-water quality stations were lower by 847 ; ground-water level stations were lower by 2,628 ; and groundwater quality stations were down by 1,368 .
\end{abstract}

\section{INTRODUCTION}

The U.S. Geological Survey operates hydrologic data-collection stations throughout the United States, Puerto Rico, and several Trust Territories. These hydrologic data-collection stations are used to monitor the quantity and quality of the water in the Nation's streams, lakes, and reservoirs; changes in ground-water levels; and the quality of ground water.

The purpose of this report is to describe the number, distribution, and source of funding of hydrologic data-collection stations operated during fiscal year (FY) 1995. Similar reports have been prepared previously for fiscal years 1983, 1985, 1987, 1989, 1991 and 1993 (Condes de la Torre, 1983, 1985, 1987, 1989, 1991 and 1993). A summary and analysis is provided of the number of hydrologic stations operated from FY 1983 to FY 1995. The sources of funding support for the stations are the U.S. Geological Survey's Federal Program appropriation, the Federal-State Cooperative Program (Gilbert and Mann, 1993), and reimbursements from other Federal agencies, or a combination of these (table 1). 


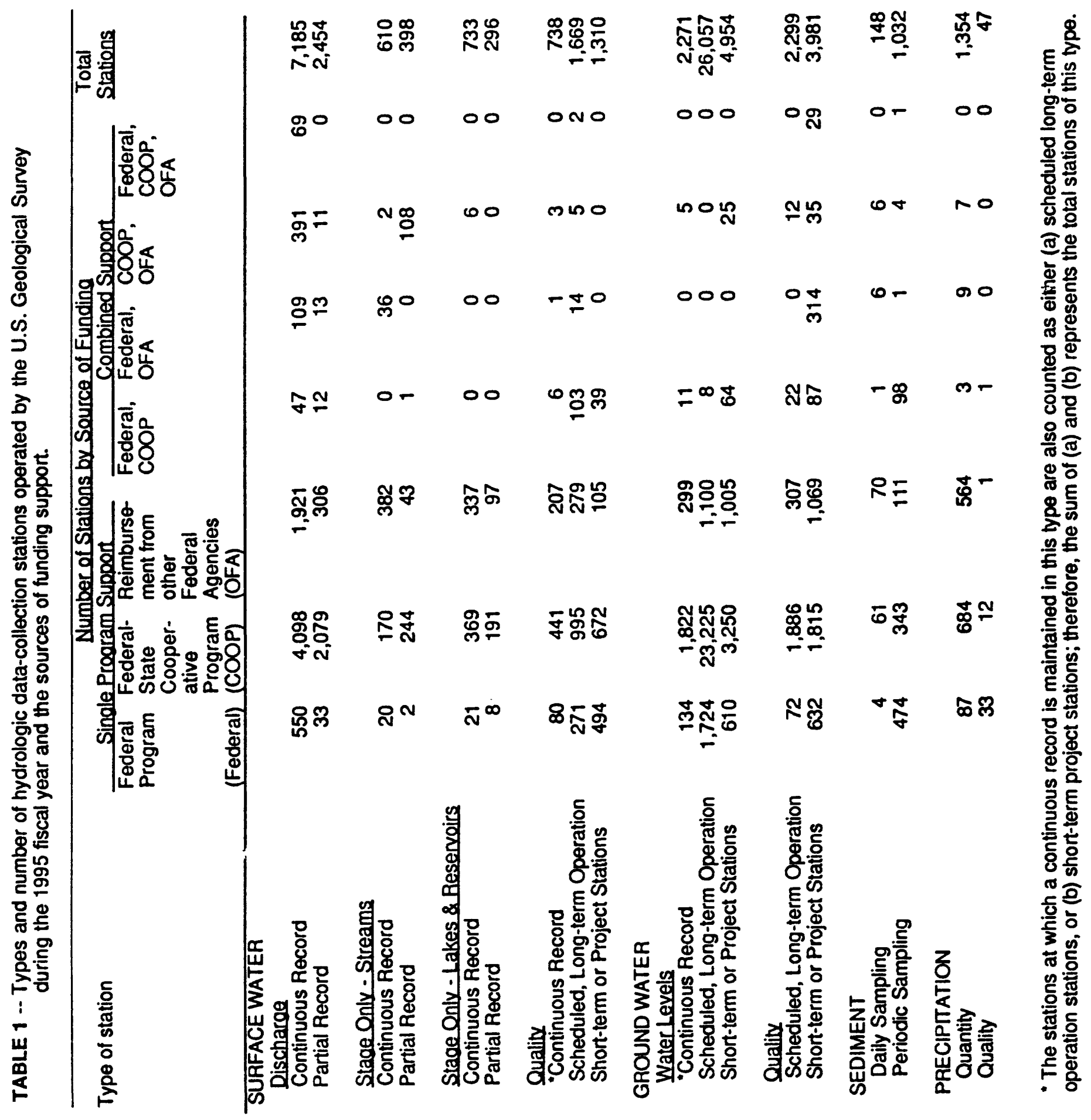


In 1983, the U.S. Geological Survey established a standard system for counting hydrologic stations so that the type of stations being counted and compared would be consistent from year to year. In 1985, the items to be counted were increased to include stations operated to collect daily and periodic sediment sampling data and information on the number of data-collection platforms. For this reason, the information presented in this report beings in either 1983 or 1985.

For the purpose of this report, "project" refers to a hydrologic investigation conducted by the U.S. Geological Survey, and a "scheduled, long-term operation" station is one at which measurements are made or samples are taken on a fixed-time interval over an indefinite period. Also, "continuous" and "continuous record" are used interchangeably.

\section{HYDROLOGIC DATA-COLLECTION STATIONS}

\section{Surface-Water Data}

Surface-water discharge (flow) was determined by the U.S. Geological Survey at 9,639 stations in FY 1995. At 7,185 of these stations, continuous-discharge records were computed. That is, records were kept such that the flow can be determined for any moment during any day. At 2,454 other streamflow stations, partial records were collected. For example, at a station where the sole interest is in peak flows, data are collected and recorded only at stages greater than some predetermined level. The number of stations in each State where continuous surface-water discharge data were collected ranged from 18 in Delaware to 719 in California (figure 1). The Federal-State Cooperative Program funded operation of the largest number of continuous surface water discharge stations; it provided sole support for 4,098 stations, and in combination with other sources, provided support for $(47,+391,+69) 507$ more (table 1). The Federal-State

Cooperative Program also funded the largest number of partial-record discharge stations; it provided sole support of 2,079 stations (table 1), and in combination with other sources, 23 more.

The number of continuous-record surface-water discharge stations varied from 7,152 stations in FY 1983 to 7,185 stations in FY 1995 (figure 2), with a low of 7,000in FY 1987 and a high of 7,363 in FY 1990. The change reflects decreases in some States and increases in others (table 2). During the same period, the number of partial record surface-water discharge stations decreased by 1,470 to 2,454 stations in FY 1995. In Nebraska, the number of discharge stations decreased by 36 from 1994 to 1995 when a State cooperator terminated funding stations in the Federal-State Cooperative Program (table 2).

Stage-only data were collected by the U.S. Geological Survey in FY 1995 at 1,008 stream stations. The number of stage-only data stations on streams ranged from none in several States to 116 in Louisiana (figure 3). The reimbursement from other Federal agencies supported the largest number of continuous stage-only stream stations--382, while the Federal State Cooperative Program supported the most partial-record stage-only stations--244 (table 1). The number of continuous-record stations collecting stage-only data on streams increased from 419 in 1983 to a high of 610 in 1995 (figure 4), whereas the number of partial-record stations decreased by 73.

Stage data were also collected at 1,029 stations on lakes and reservoirs by the U.S. Geological 
Table 2. -- Number of continuous surface-water discharge stations, by State and year, from fiscal year 1983 to 1995

\section{NUMBER OF STATIONS}

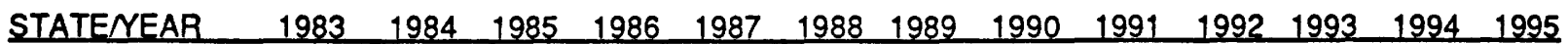

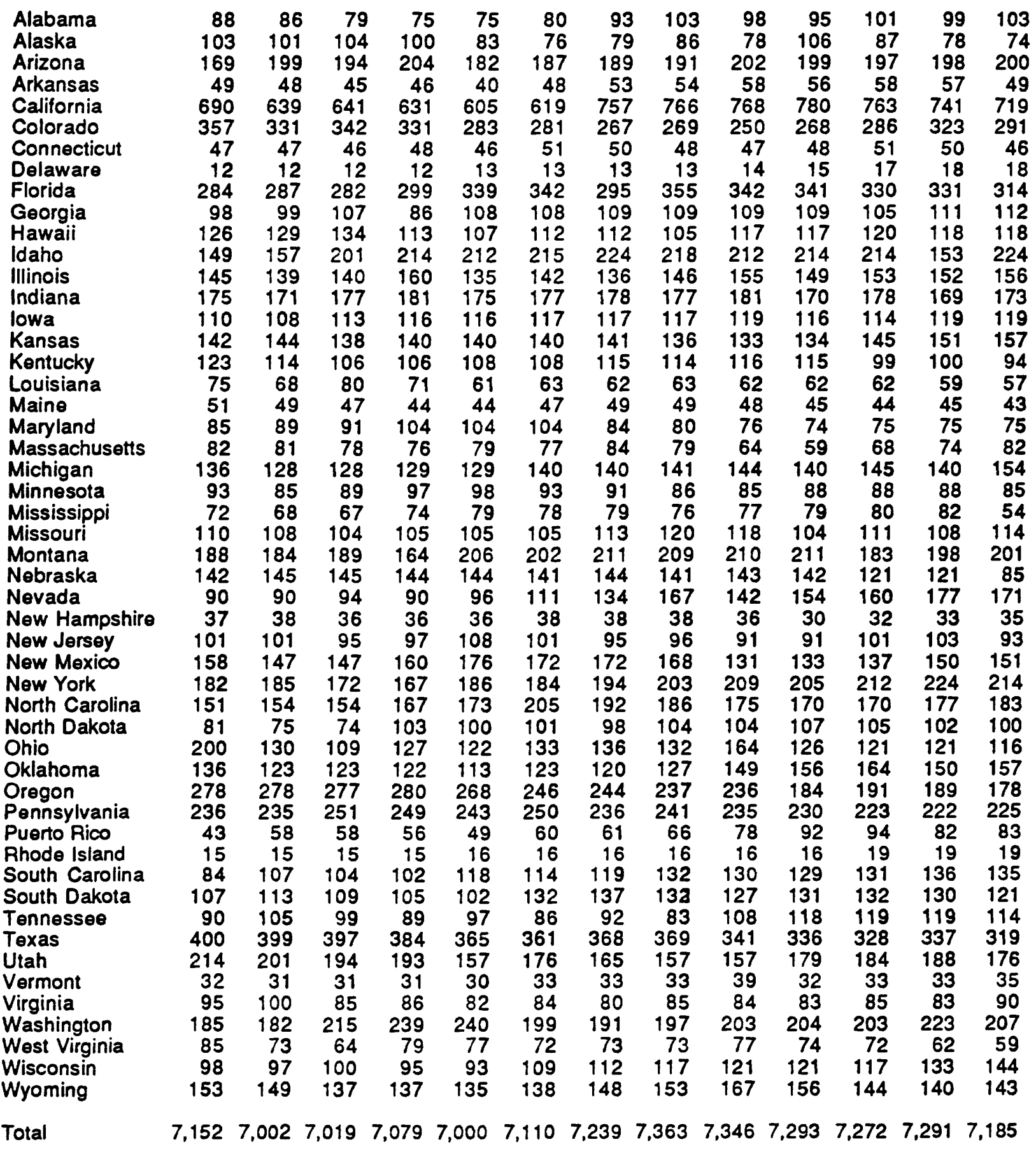


Survey. Continuous records of stage were collected at 733 lake and reservoir stations, ranging from 133 in California to none in several States (figure 5). Reimbursements from the FederalState Cooperative Program and other Federal agencies supported over 95\% of the continuousrecord stations and partial-record stage stations on lakes and reservoirs (table 1). The number of stage stations on lakes and reservoirs decreased from 1,246 in FY 1983 to 1,029 in FY 1995 (figure 6).

Stream samples were collected and analyzed for water-quality characteristics at 2,979 stations across the Nation (figure 7). The types of chemical constituents and physical properties measured vary from site to site. Field determinations could include those for temperature, specific conductance, $\mathrm{pH}$, dissolved oxygen, fecal coliform, and fecal streptococci. Laboratory determinations could include those for common constituents such as calcium, magnesium, fluoride, sodium, potassium, dissolved solids, silica, chloride, sulfate, hardness, bicarbonate, carbonate, and turbidity; for major nutrients such as phosphorus, ammonia, nitrite, and nitrate; trace metals such as arsenic, cadmium, chromium, cobalt, copper, iron, lead, manganese, mercury, selenium, and zinc; and for selected radiochemical parameters. A continuous record was maintained at 738 of these sites, mainly for water temperature and conductance, but other properties, such as dissolved oxygen concentrations and $\mathrm{pH}$, were also recorded continuously at times. The surface-water quality stations at which a continuous record is maintained are also counted as either (a) scheduled long-term operation stations, or (b) short-term project stations; therefore, the sum of (a) and (b) represents the total stations of this type.

There were 1,310 stations in FY 1995 which were sampled as short-term or project stations. The collection of surface-water quality data received its largest funding support from the Federal-State Cooperative Program for all types of stations. Water quality data were collected at 1,669 stream sites as part of a scheduled, long-term operation (table 1). These include 142 stations, supported in the U.S. Geological Survey's Federal Program, which make up the National Stream Quality Accounting Network (NASQAN).

NASQAN was established by the U.S. Geological Survey to provide a uniform basis for continually assessing the quality of water in the United States streams. In 1993 there were 386 stations that measured an identical suite of water-quality characteristics at each NASQAN station using the same set of procedures concerning sample-collection techniques, frequency of sampling, and analytical methods (Briggs and Ficke, 1977). Because of funding considerations, measurement of additional constituents such as pesticides, and upgraded quality assurance/quality control measures, the number of stations in the NASQAN network has been in decline.

The number of stations at which surface-water quality data were collected on a scheduled, longterm basis increased in some States, but he overall total declined from 2,906 in FY 1983 to 1,669 in FY 1995 (figure 8). The decline includes the changes in the NASQAN program. In Wyoming, for example, the number of scheduled, long-term sampling stations was reduced from FY 1983 to FY 1995 when the State's emphasis changed from analyses for major dissolved constituents to more expensive analyses for pesticides and herbicides. Thus, in order to accommodate to a static level of available funds, the number of sampling stations had to be decreased. 


\section{Ground-Water Data}

Ground water is one of the most widely available of the Nation's natural resources. It is estimated that 79 billion gallons per day of ground water are withdrawn in the United States for public supply domestic, commercial, irrigation, livestock, industrial, mining, and thermo-electric uses (Solley and others, 1993). Water-level fluctuations are indicators of the stresses (both natural and man-induced) placed on aquifers, their ability to yield water, and the quantity of water in storage beneath the earth's surface. The U.S. Geological Survey collected information on ground-water levels at 31,011 sites in 1995 and water levels were recorded continuously at 2,271 sites, of which 1,822 were funded in total by the Federal-State Cooperative Program. The stations at which a continuous record of ground-water levels is maintained are also counted as either (a) scheduled, long-term operation stations, or (b) short-term project stations; therefore, the sum of (a) and (b) represents the total stations of this type. Ground-water levels were measured at 26,057 stations as part of a scheduled, long-term operation to assess long-term trends (figure 9). When special area studies were conducted, water levels were at times measured at short-term or project stations to supplement the information available in the area from the long-term stations. In 1995, water-level data were collected at 4,954 stations for these investigations. The Federal-State Cooperative Program provided total funding support for 85 percent of the long and short-term stations (table 1). Nebraska has the greatest number of ground-water level stations (figure 9).

From FY 1983 to FY 1995, the number of scheduled, long-term operation ground-water level stations increased from 24,047 in FY 1983 to 26,057 in FY 1995 (figure 10). The number of stations at which ground-water levels were measured continuously also increased from 1,982 in FY 1983 to 2,271 in FY 1995. Meanwhile, the short-term or project stations increased from 9,592 in FY 1983 to 11,994 in FY 1985, and then decreased 4,954 in FY 1995.

In FY 1995, samples of ground water from 6,280 stations nationwide were analyzed (figure 11). To maintain information on the changes in quality of critical ground-water bodies, samples were collected at 2,299 stations as part of a scheduled long-term operation. Of these, sampling at 1,886 stations was funded in total by the Federal-State Cooperative Program. Ground-water quality data were also collected at 3,981 stations to provide information needed for short-term, generally site-specific, studies (table 1).

Across the country, the number of stations at which ground-water quality samples were collected has varied from a low of 5,671 in FY 1984 to a high of 9,756 in FY 1986 (figure 12).

\section{$\underline{\text { Sediment Data }}$}

Data are needed to evaluate the effect of sediment deposition on reservoir storage; the influence of infrequent large storms on erosion and transport of sediment; and the effects of urban and rural non-point contributions of sediment and the associated transport and fate of nutrients, toxic metals, and organic substances. Burkham (1985) states: "The U.S. Geological Survey (USGS) and other Federal, State, and local agencies obtain records of suspended-sediment discharge at many sites throughout the United States. The use of these records has greatly increased in recent years. Uses involve the evaluation of sediment transport to the oceans, geomorphological studies of denudation and rates of erosion, assessment of soil erosion and soil loss, reservoir sedimentation, general environment impact assessment, water treatment problems of sediment-associated 
nutrients and pollutants, and evaluation of the precise impacts of humans."

Field techniques to collect suspended sediment samples were tested to determine whether or not they produce a representative sample of sediment for chemical analysis. The collection methods were found to produce representative sediment samples for chemical analyses; however, new protocols are needed for equipment cleaning and identifying noncontaminated equipment. These new protocols are being written. These techniques will be of use in determining the fate of toxic subtances in river systems. The movement of sediment into reservoirs and estuaries, and the associated chemical processes, must be understood because sediment can provide a potential source of toxic substances that could have a serious impact on the local biota and the food chain, as well as directly on water supplies.

To help address the problems and issues of sediment in rivers, the U.S. Geological Survey collected daily sediment data at 148 stations, and periodic data at 1,032 other stations in FY 1995 (figure 13). From FY 1985 to FY 1995 the number of stations has varied from the high in FY 1985 of 1,239 (figure 14).

\section{Precipitation Data}

Precipitation data are collected by the U.S. Geological Survey only as part of an investigation of a specific hydrologic system. Most of the time, precipitation data from the National Weather Service are used in U.S. Geological Survey investigations. Precipitation data were collected at 1,354 sites nationwide (figure 15). At 47 of these sites, quality of precipitation was determined. The largest support for the collection of precipitation quantity and quality data came from the Federal-State Cooperative Program and the Federal Program, respectively (table 1). The number of sites at which precipitation data were collected increased from 800 in FY 1983 to 1,354 in FY 1995 (figure 16).

\section{SATELLITE TELEMETRY OF HYDROLOGIC DATA}

Satellite telemetry is playing an increasing role in the collection of hydrologic data in real time. A satellite data-collection system consists of data-collection platform (which is a small batteryoperated radio), and Earth-orbiting satellite, and an Earth receive and data-processing station. The demand for a cost-effective means of collecting hydrologic data in real-time for hazardwarning systems and water management has increased rapidly (Paulson and Shope, 1984). In FY 1995, data-collection platforms were located in 3,920 U.S. Geological Survey hydrologic data-collection stations and were transmitting data for one, or a combination, of the following parameters: stream stage, reservoir stage, water quality, and precipitation (figure 17). There were 3,404 stations at which data-collection platforms were operated by the U.S. Geological Survey and 516 U.S. Geological Survey stations at which the data-collection platforms were operated by others. Over half of the funding for the U.S. Geological Survey operation of the data-collection platforms is provided by other Federal agencies (figure 18). The number of data-collection platforms located in U.S. Geological Survey hydrologic stations increased from 1,520 in FY 1985 to 3,920 in FY 1995 (figure 19). 


\section{SUMMARY}

The U.S. Geological Survey operates an extensive, nationwide network for the collection of hydrologic data. The surface-water data include information on discharge and stage of streams, stages of lakes and reservoirs, and surface-water quality. Data are also collected on ground-water levels and the quality of ground water. Data on sediment are collected on a daily and periodic basis. Data on the quantity and quality of precipitation are usually collected only in selected study areas. Satellite telemetry is being used to collect hydrologic data in real-time. From FY 1983 to FY 1995 the total number of surface-water discharge stations declined. The number of continuous-record discharge stations increased, surface-water quality stations declined, and ground-water level and ground-water quality stations both decreased. 


\section{REFERENCES CITED}

Briggs, J.D., and Ficke, J.F., 1977, Quality of Rivers of the United States, 1975 Water Year-Based on the National Stream Quality Accounting Network (NASQAN): U.S. Geological Survey Open-File Report 78-200, 436 p.

Burkham, D.C., 1985, An Approach for Appraising the Accurancy of Suspended-sediment Data: U.S. Geological Survey Professional Paper 1333, 18 p.

Condes de la Torre, A., 1983, Operation of Hydrologic Data-Collection Stations by the U.S. Geological Survey in 1983: U.S. Geological Survey Open-File Report 83-862, 29 p.

, 1985, Operation of Hydrologic Data-Collection Stations by the

U.S. Geological Survey in 1985: U.S. Geological Survey Open-File Report 85-640, 37 p.

, 1987, Operation of Hydrologic Data-Collection Stations by the

U.S. Geological Survey in 1987: U.S. Geological Survey Open-File Report 87-563, 42 p.

1989, Operation of Hydrologic Data-Collection Stations by the

U.S. Geological Survey in 1989: U.S. Geological Survey Open-File Report 90-171, 52 p.

, 1991, Operation of Hydrologic Data-Collection Stations by the

U.S. Geological Survey in 1991: U.S. Geological Survey Open-File Report 92-172, 50 p.

1993, Operation of Hydrologic Data-Collection Stations by the

U.S. Geological Survey in 1993: U.S. Geological Survey Open-File Report 94-84, 53 p.

Gilbert, B.K., and Mann, W.B., IV, 1993, The U.S. Geological Survey Federal-State Cooperative Water-Resources Program Fiscal Year 1992: U.S. Geological Survey Open-File Report 93-120, $33 \mathrm{p}$.

Paulson, R.W., and Shope, W.G., Jr., 1984, Development of Earth Satellite Technology for the Telemetry of Hydrologic Data: Water Resources Bulletin, v. 20, no. 4, p. 611-618.

Solley, W.B., Pierce, R.R., and Perlman, H.A., 1993, Estimated Use of Water in the United States in 1990: U.S. Geological Survey, Circular 1081, 76 p. 


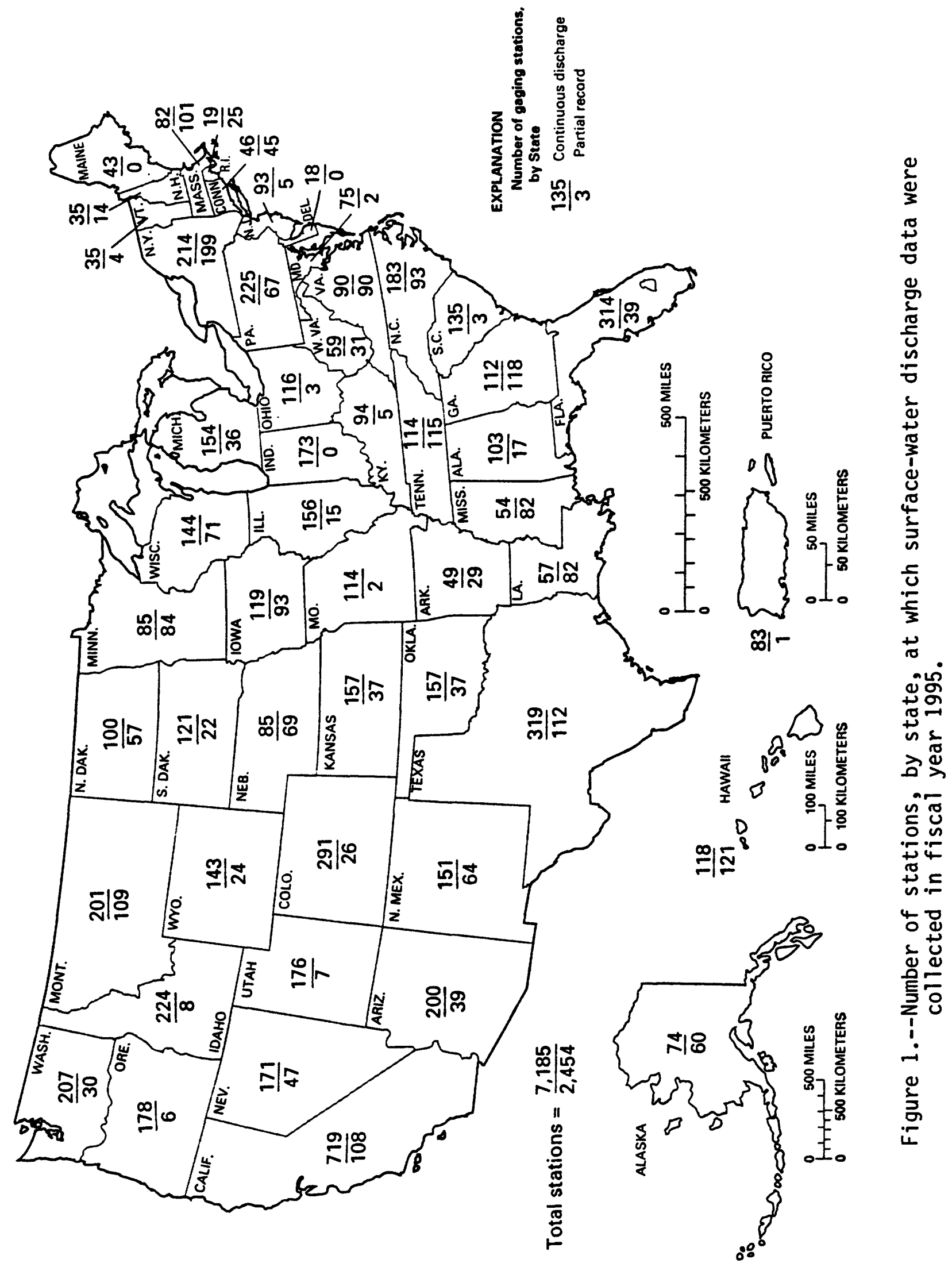




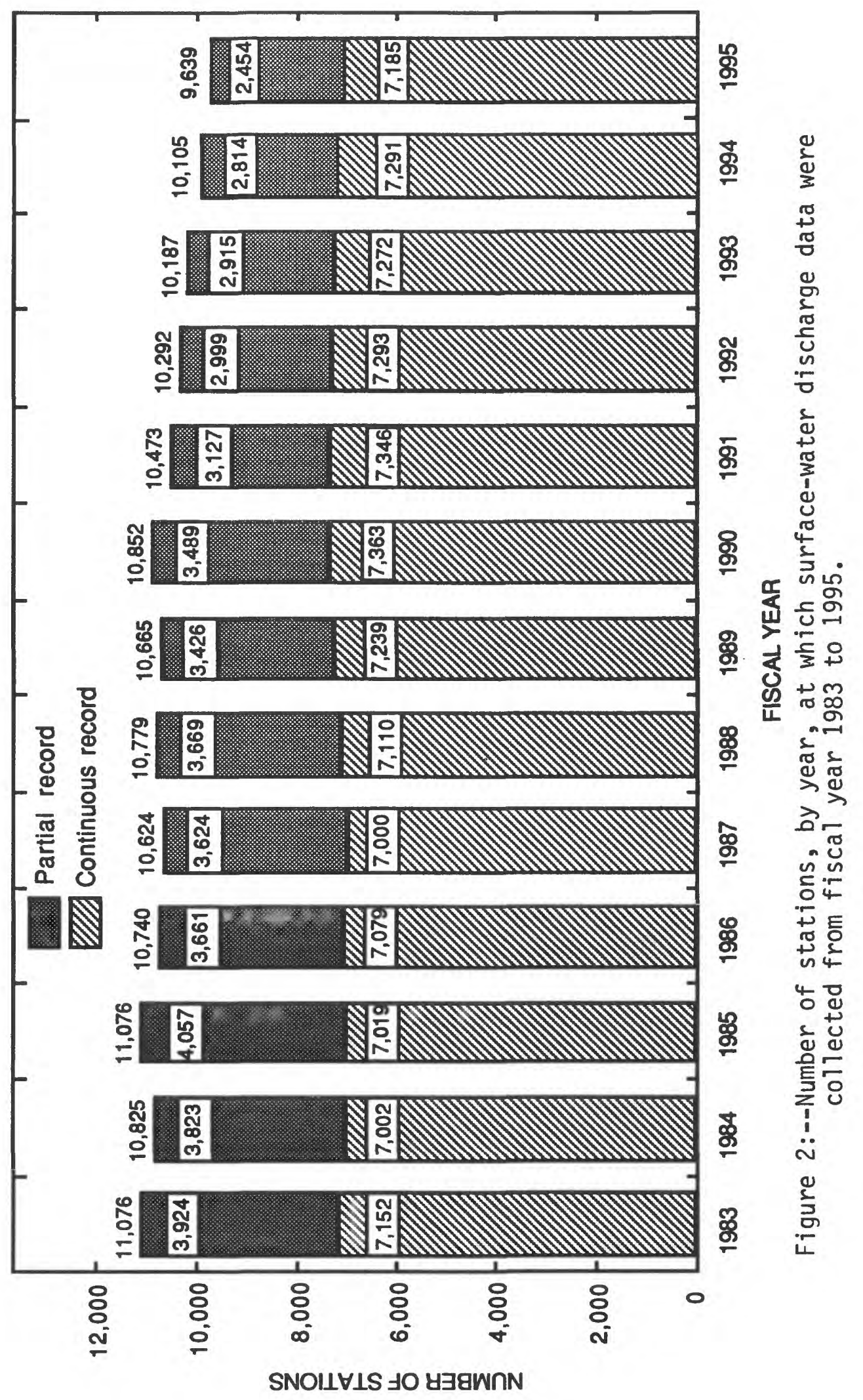




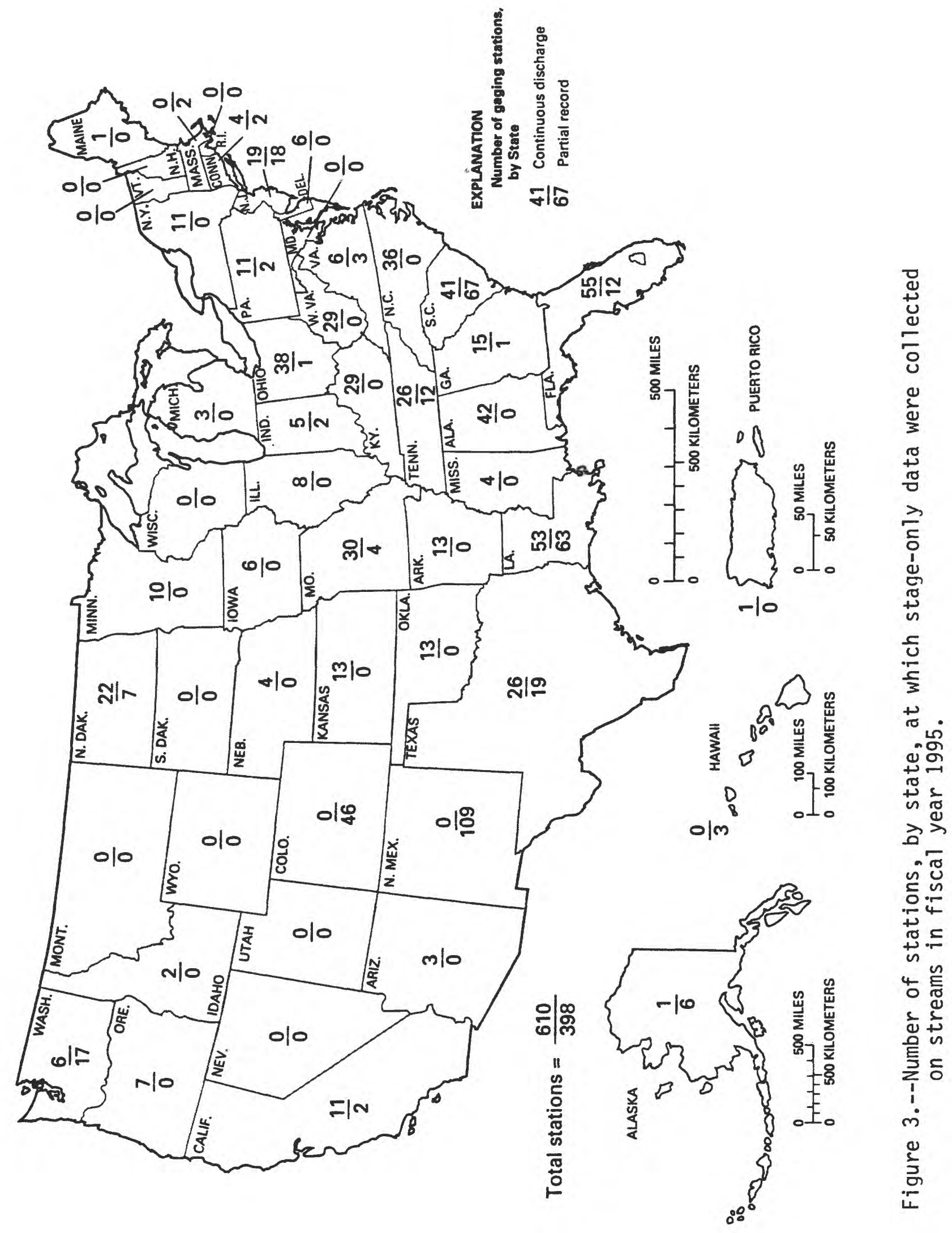




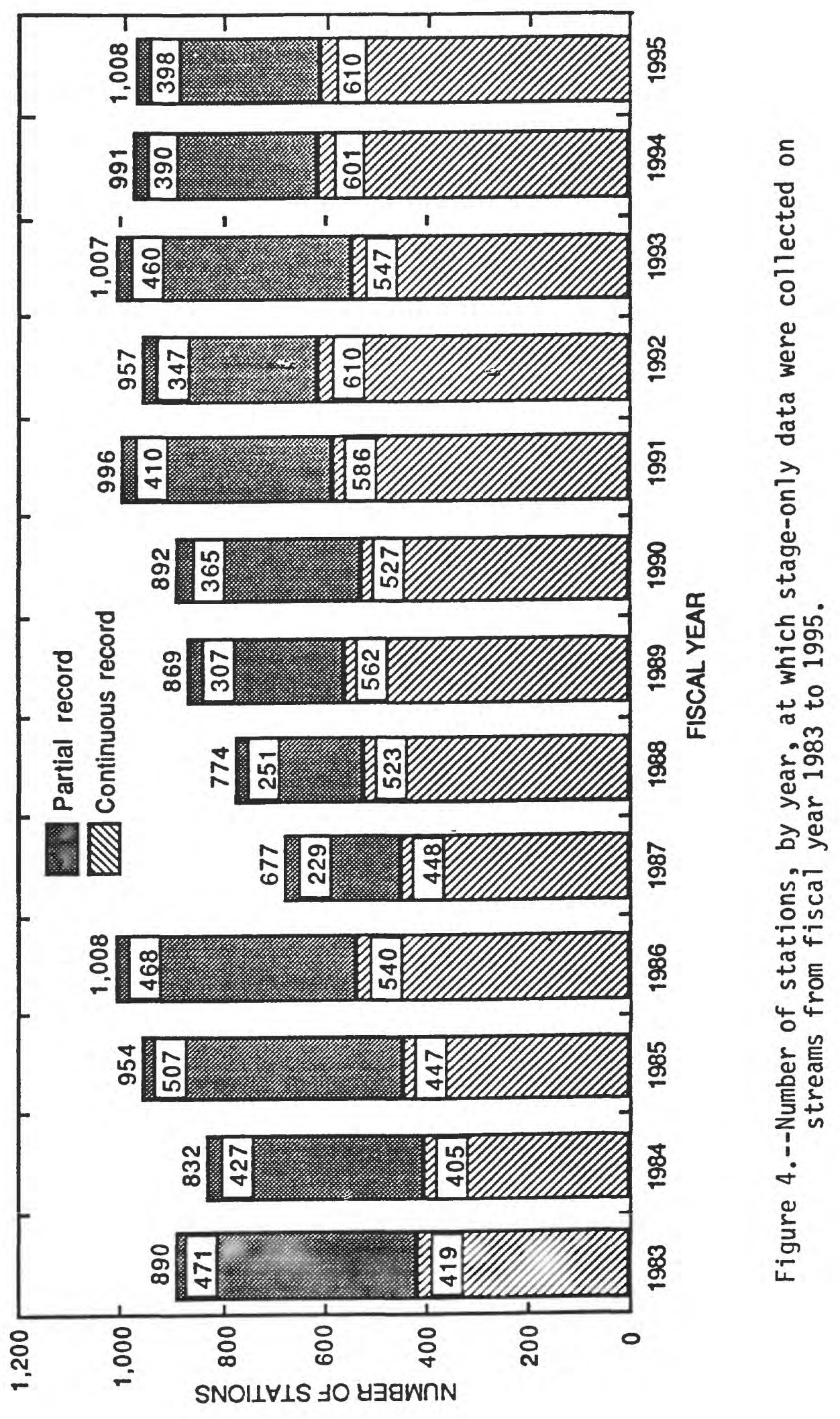




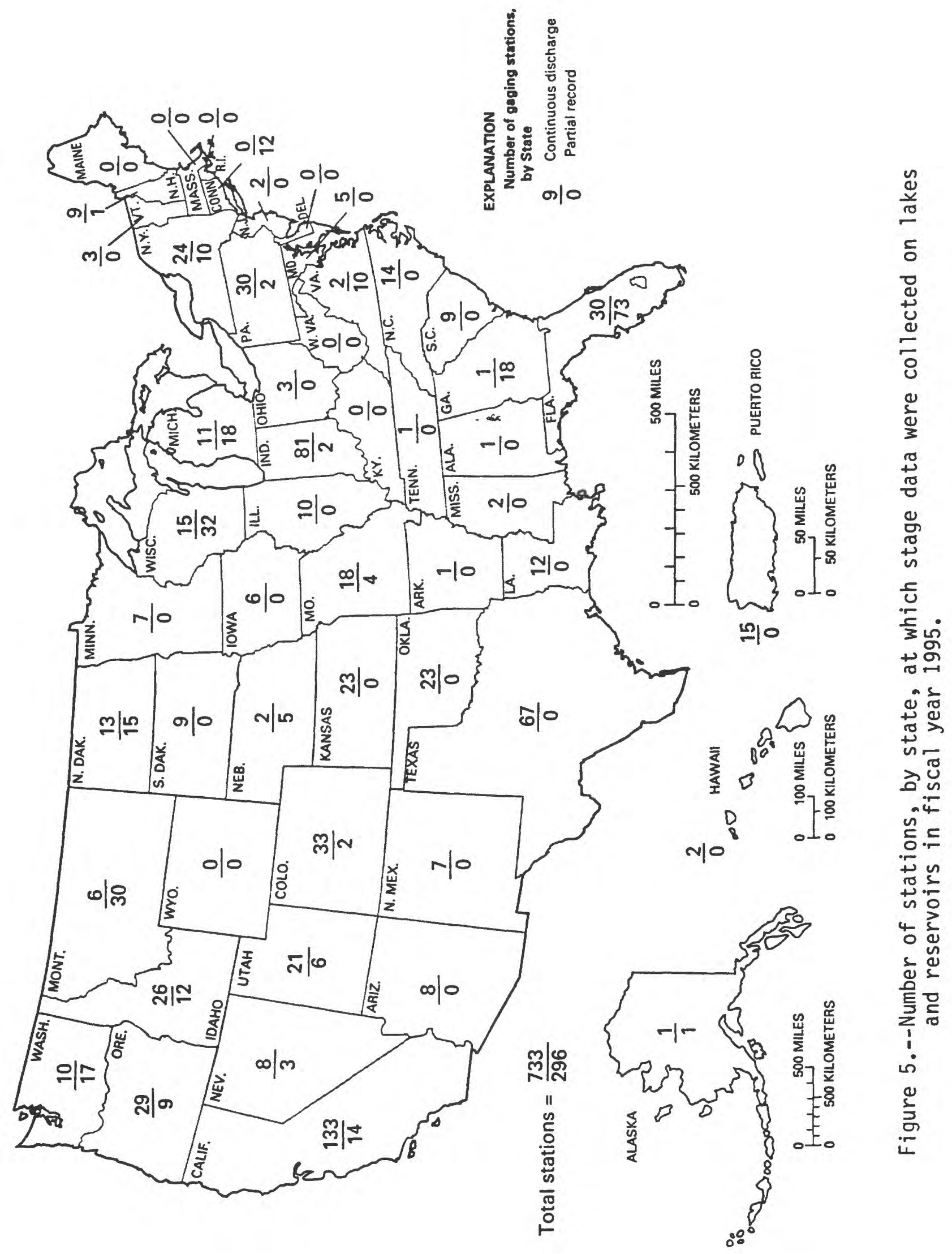




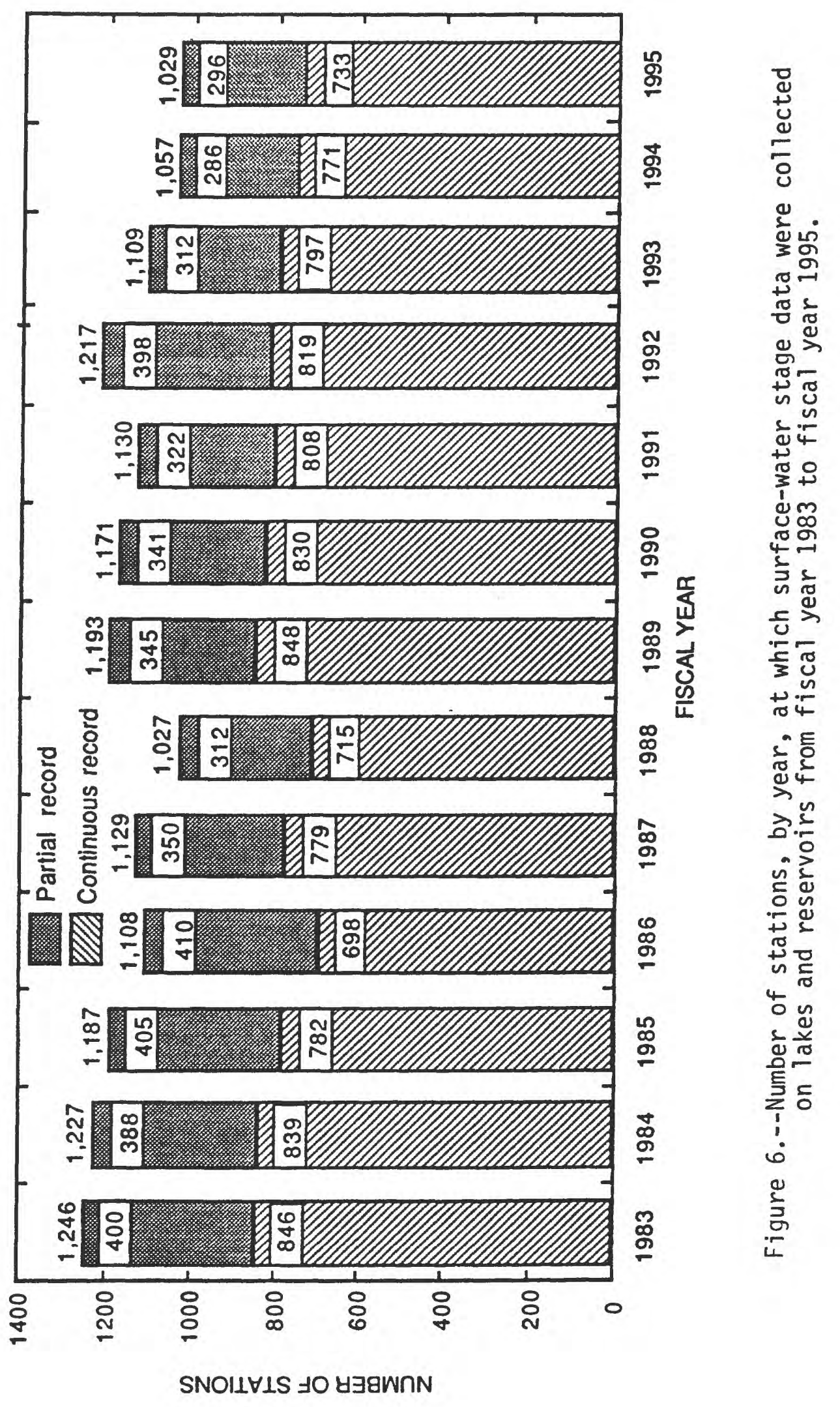




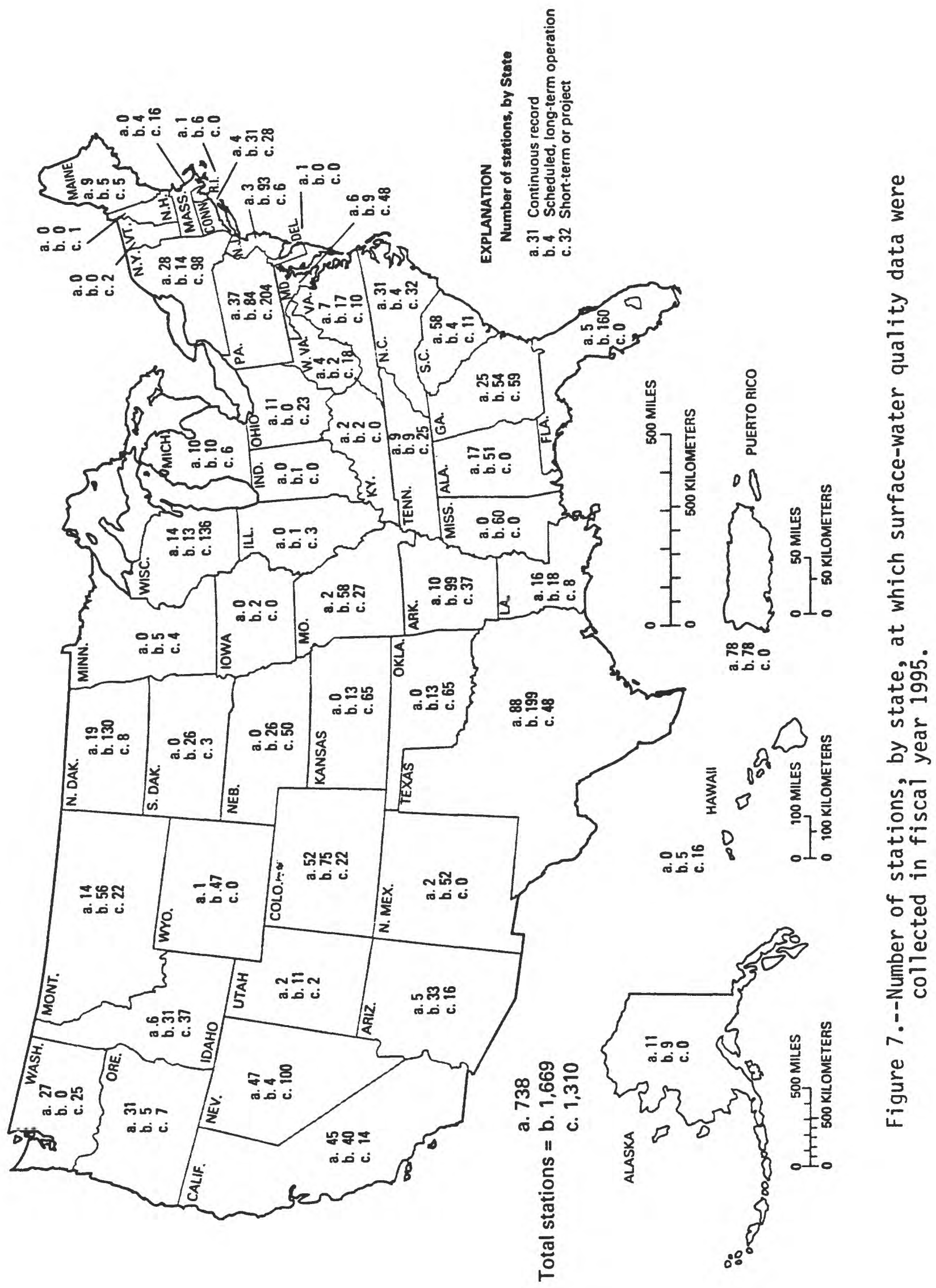




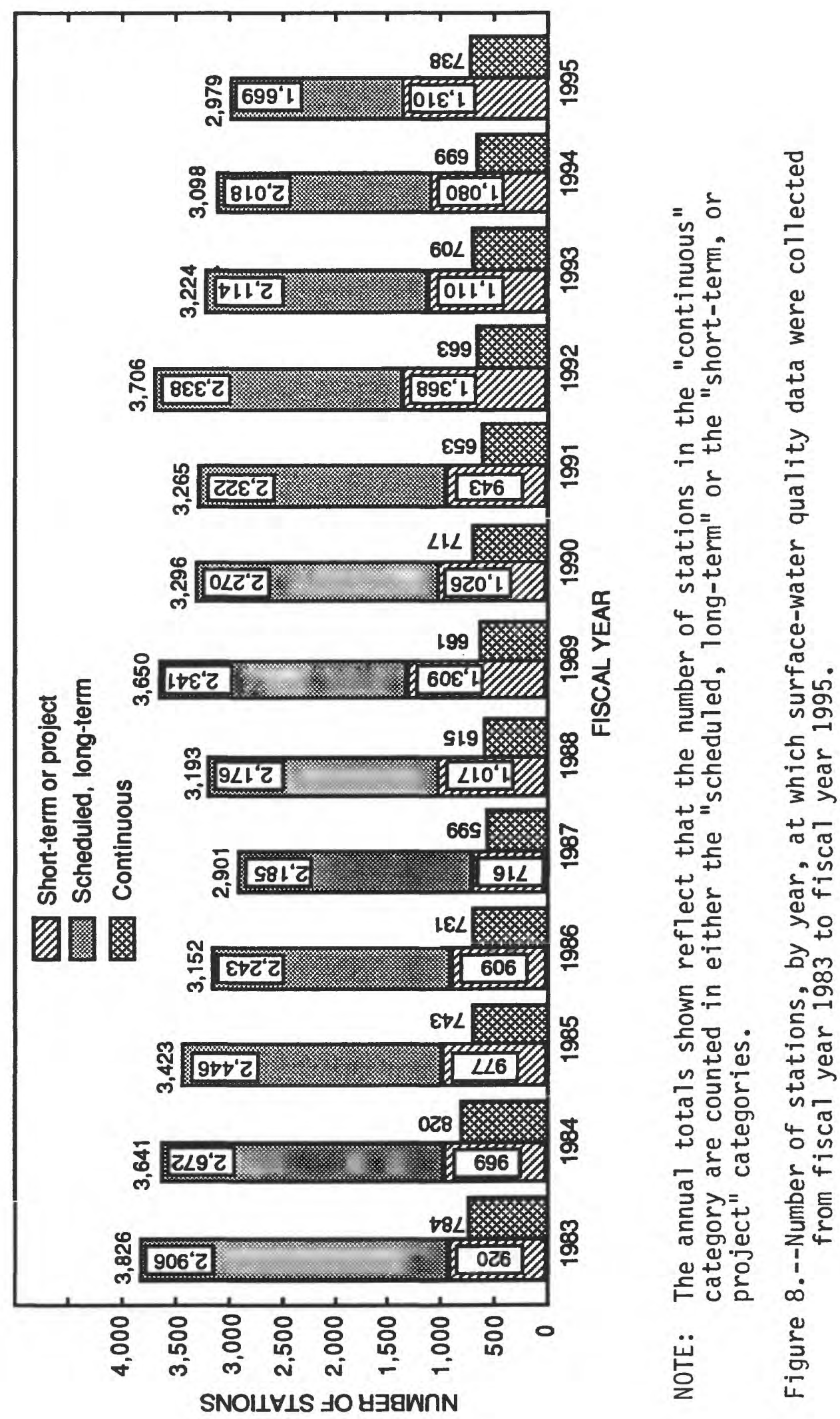




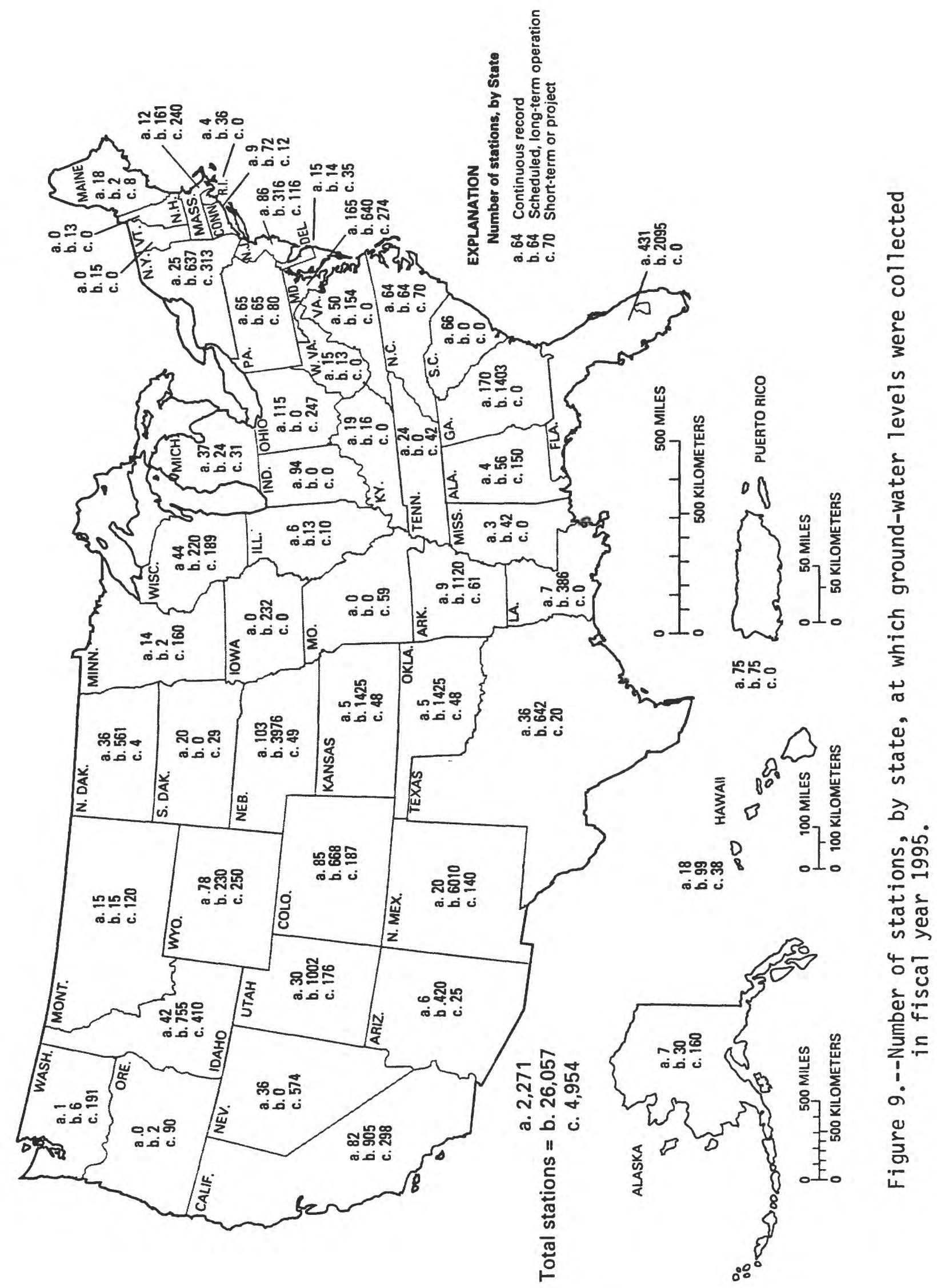




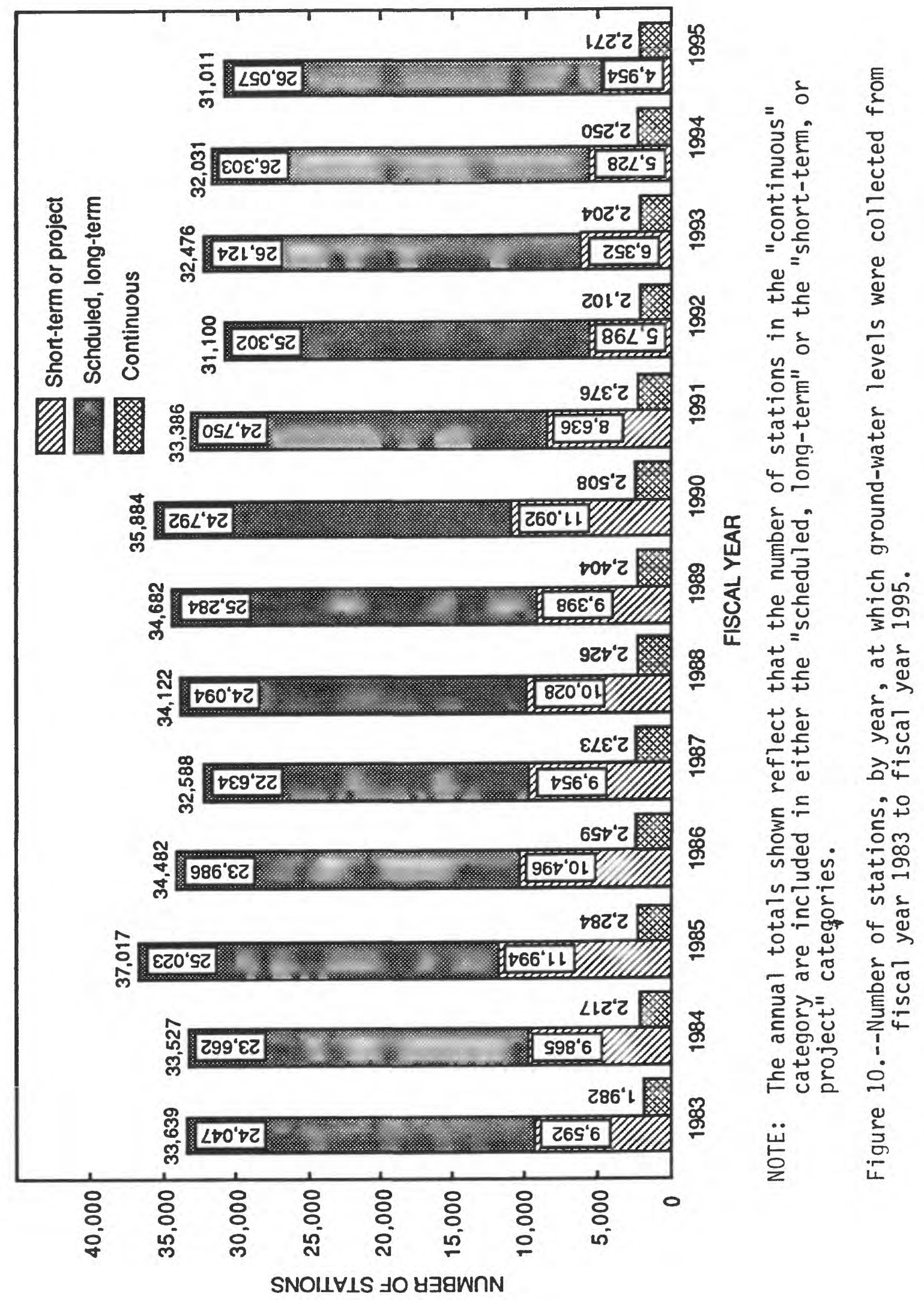




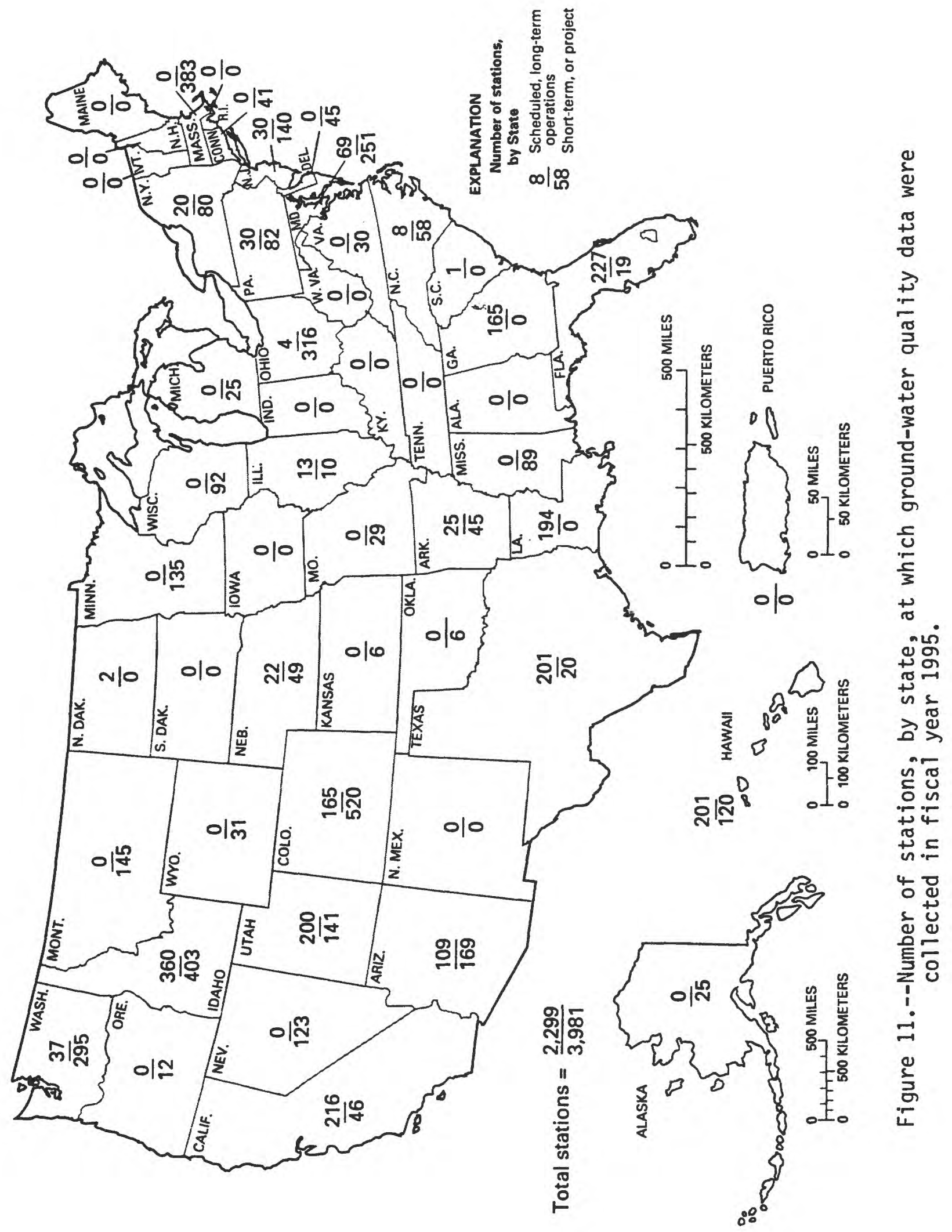




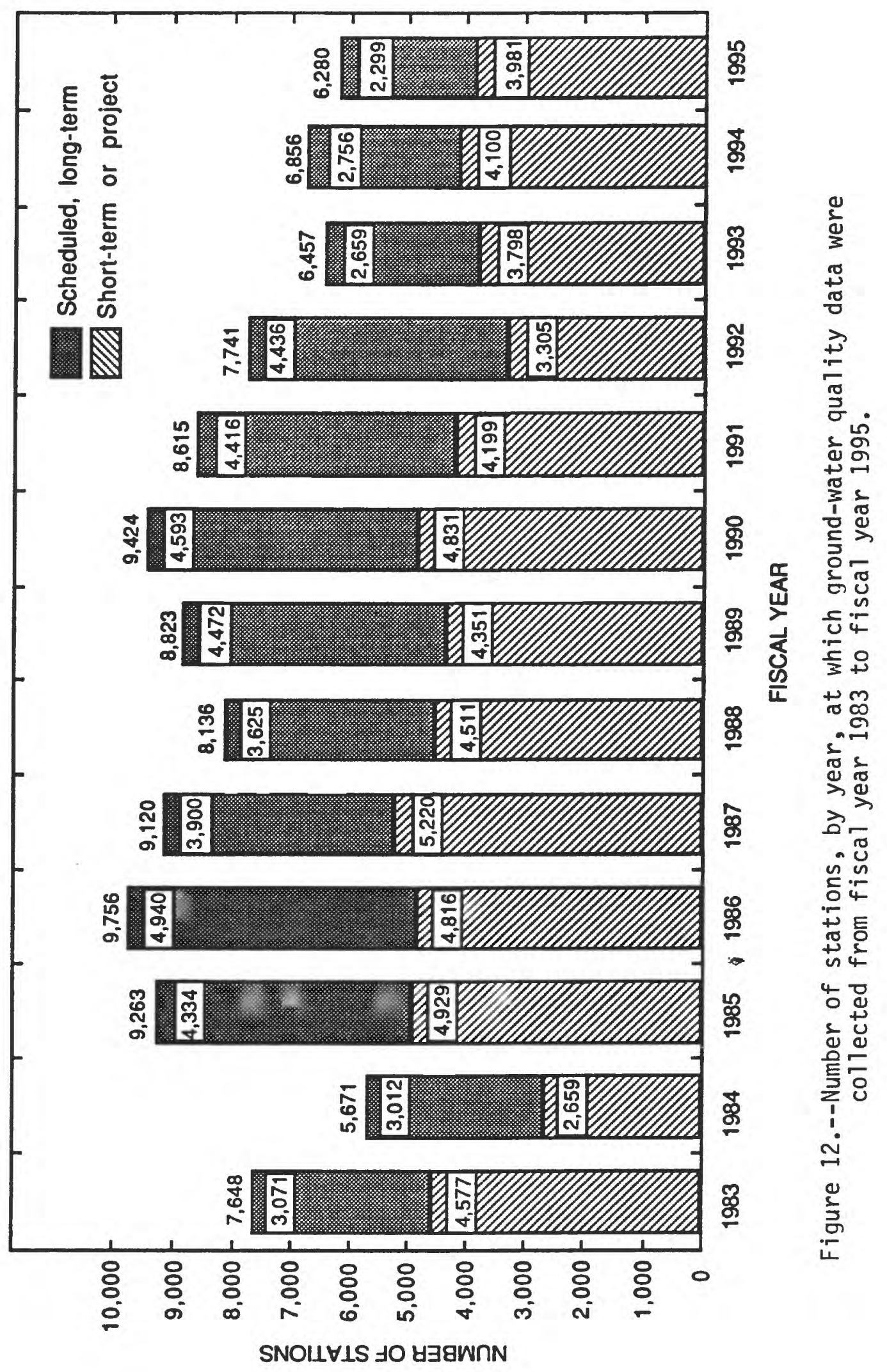




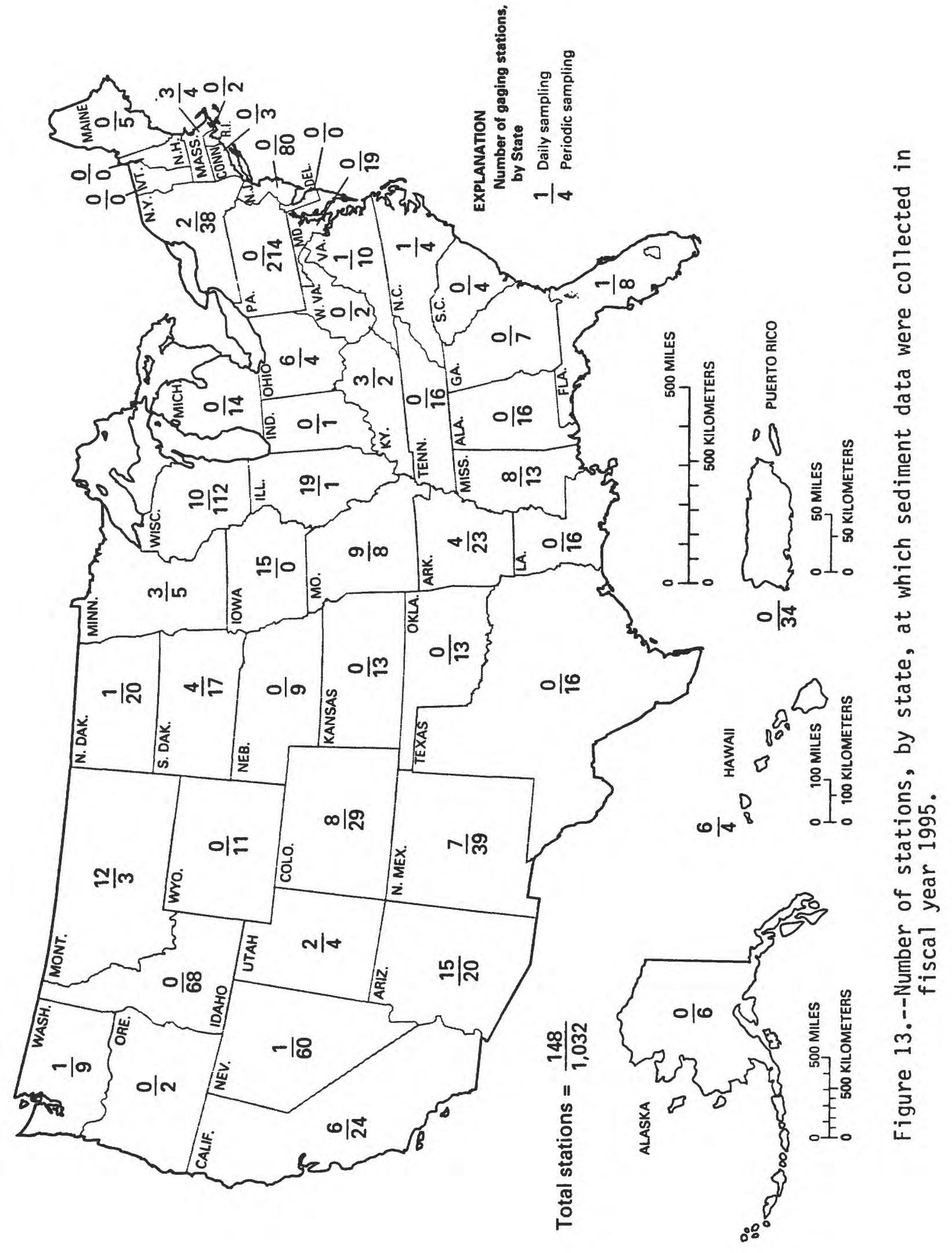




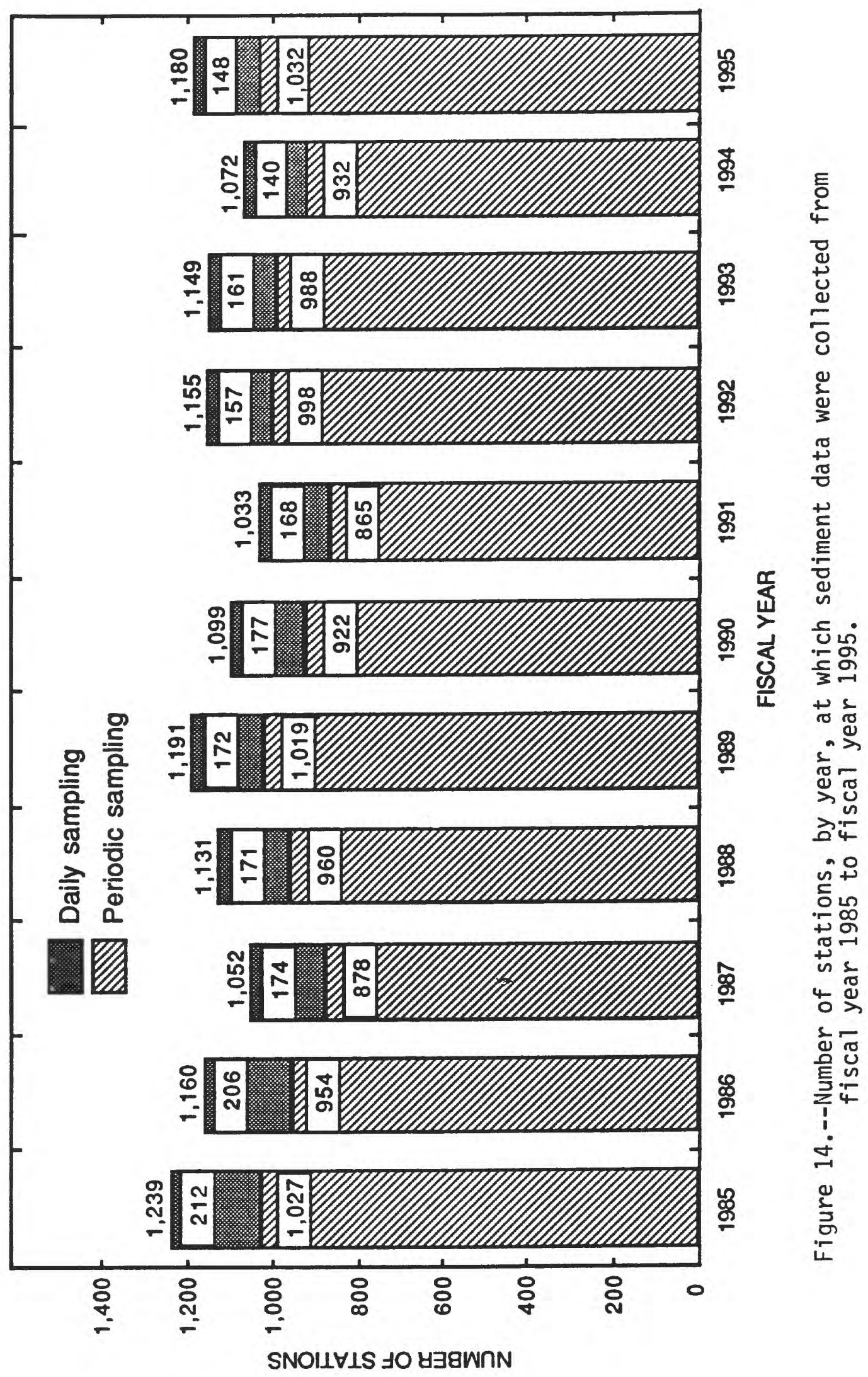




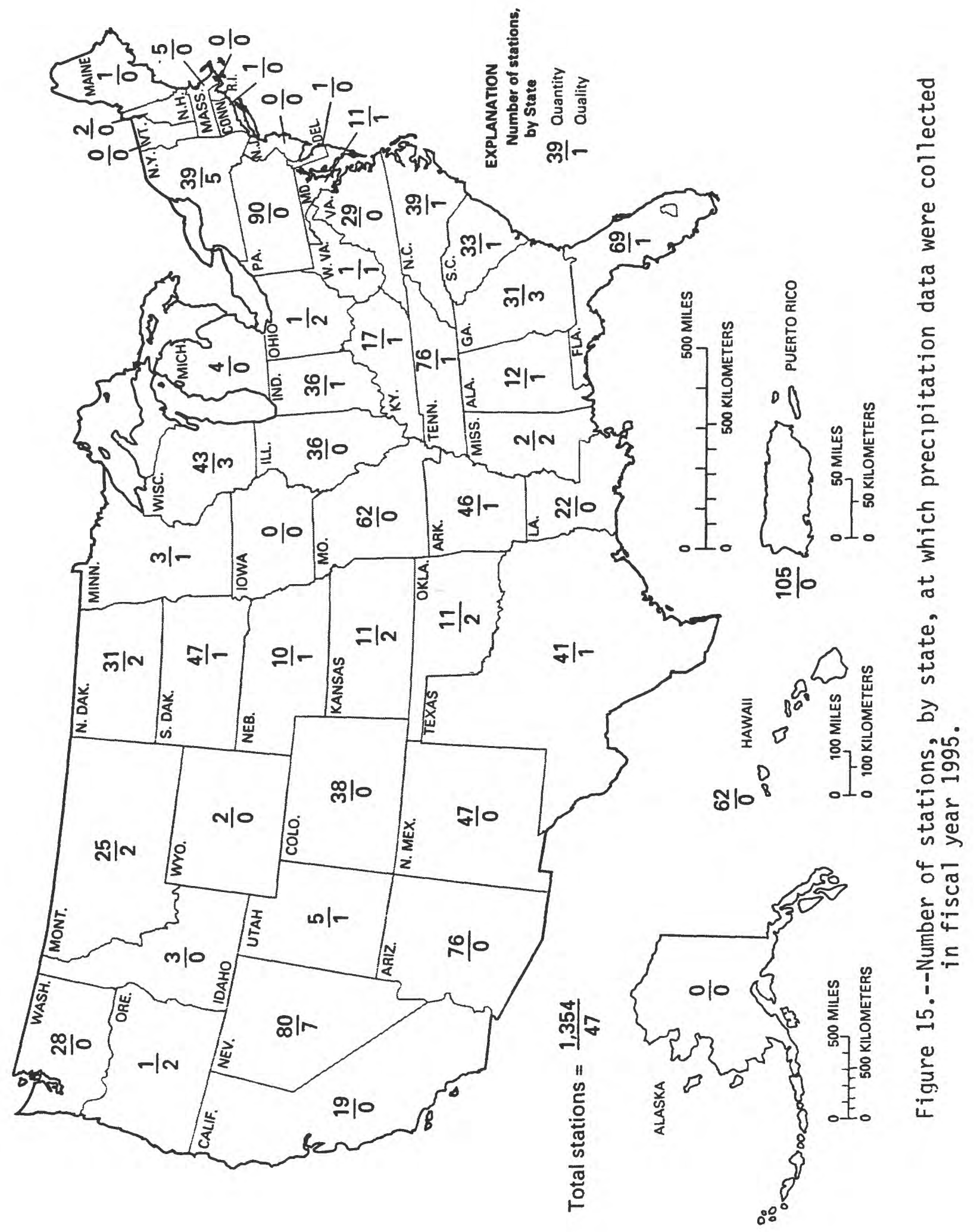




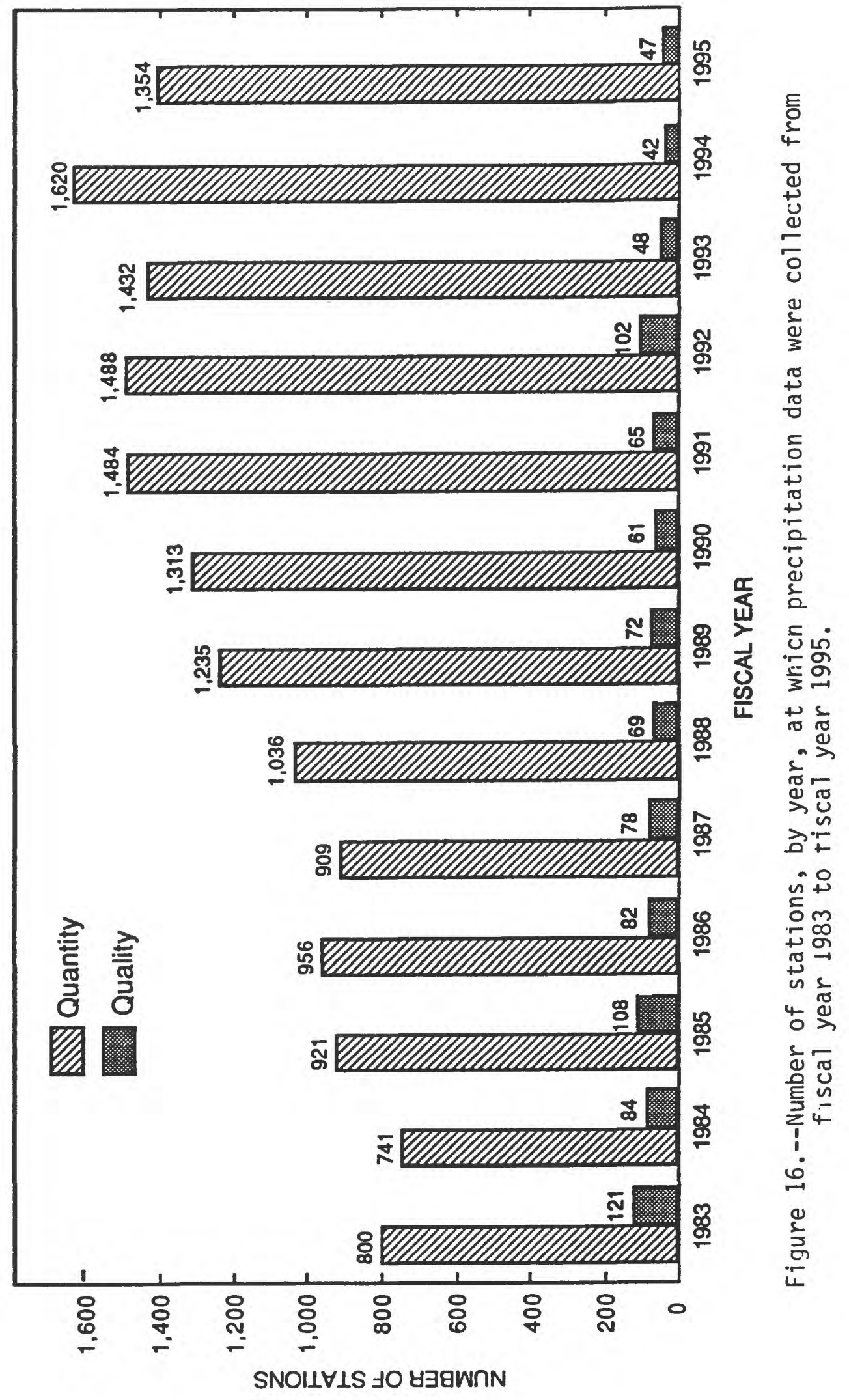




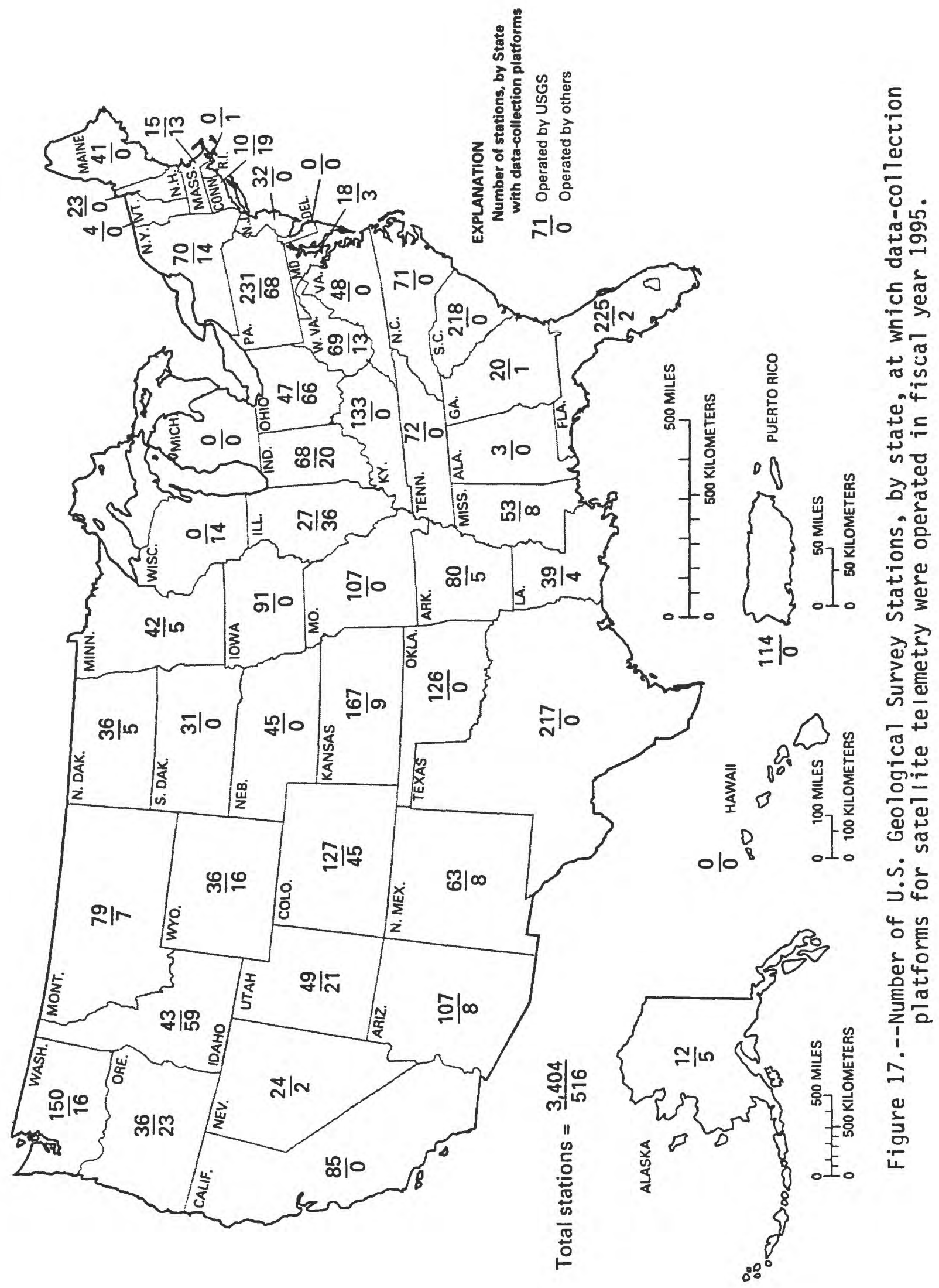




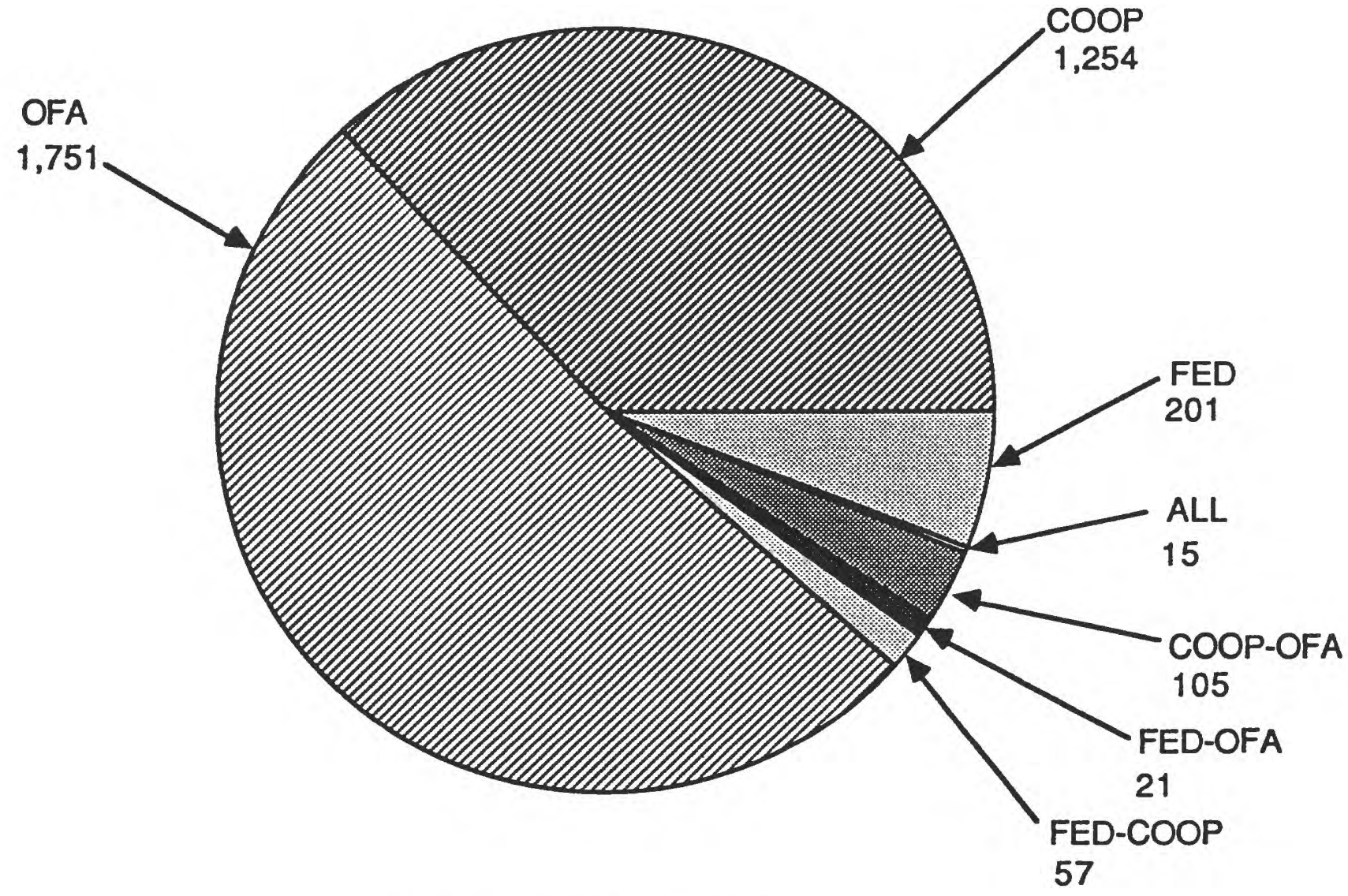

TOTAL STATIONS $=3,404$

\section{EXPLANATION}

SINGLE PROGRAM SUPPORT

FED $=$ Federal

OFA $=$ Other Federal Agencies

COOP = Federal - State Cooperative Program

COMBINED PROGRAMSUPPORT

FED - COOP = Federal and Federal - State Cooperative Program

COOP-OFA = Federal - State Cooperative Program and Other Federal Agencies

FED-OFA = Federal and Other Federal Agencies

$A L=F E D$ and $O F A$ and $C O O P$

Figure 18.--Number of stations at which data-collection platfurms for satellite telemetry were operated by the U.S. Geological Survey, and sources of funding support, fiscal year 1995. 


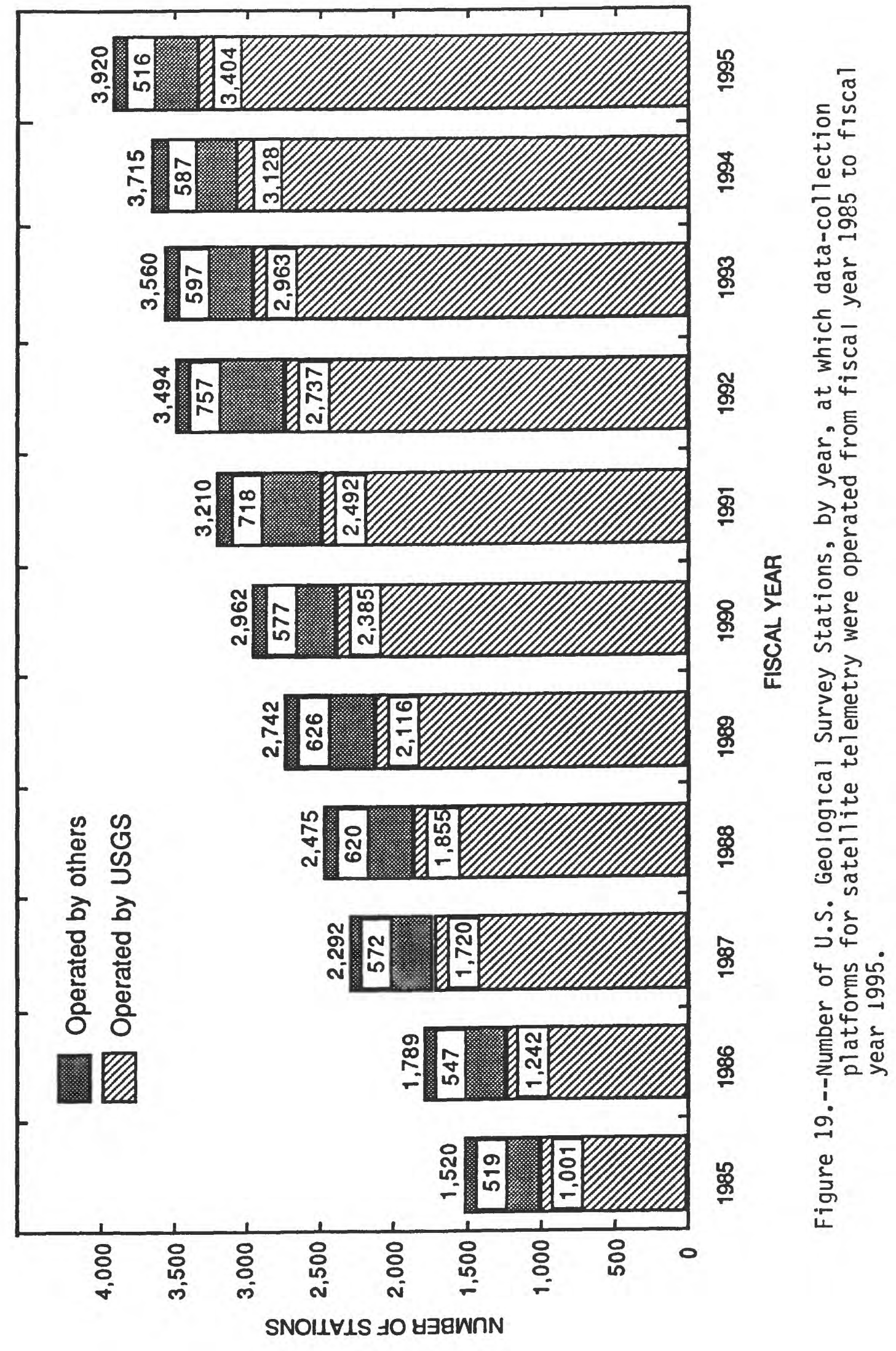

